Vieira Terra, Tatiana.

Investigadora alumna de doctorado de la Universidad de Brasilia, Instituto de artes - IdA- UnB, línea de Poéticas Contemporáneas.

\title{
El invisible y la no-materialidad de las cosas de la isla.
}

\section{The invisible and non-materiality of the things of the island.}

\author{
TIPO DE TRABAJO:
}

Comunicación.

PALABRAS CLAVE:

Cosas, voces, perspectivismo, invisibilidad.

KEY WORDS:

Things, voices, perspectivism, invisibility.

RESUMEN

Una isla situada en la meseta central del Brasil se convierte en el espacio gravitacional de un viaje artístico de exploración. Despegues y fluctuaciones alternan durante la expedición. Estar en la isla también significa ser el punto focal de una telescopio invertido donde el dialogo se construye a partir de las cosas que habitan en los espacios cercanos e infinitos, en el flujo de las relaciones entre ellas y el sujeto en el espacio. Las narrativas visuales proporcionadas por el viaje, surgieron a partir de los deseos, de las confrontaciones y de las sorpresas vividas durante las pausas y comuniones invocadas por la no materialidad de las cosas que viven allí. El texto narra la expedición a la isla, trae imágenes producidas a partir de la experiencia vivida e invita a una reflexión sobre las voces silenciosas de las cosas en el espacio, la visión invisible y la resonancia interna del sujeto.

\section{ABSTRACT.}

An island located in the central plateau of Brazil turns into a gravitational space of an artistic journey of exploration. Landings and fluctuations alternate during the expedition. Being on the island also means being the focal point of a reversed telescope where the dialogue is constructed from the things that inhabit the near and infinite spaces, the flow of relationship between them and the subject in space. The visual narratives provided by the journey were made from the desires, confrontations and bewilderment which were all experienced during the pauses and communions invoked by the non-materiality of the things that live there. The text narrates the expedition to the island, it brings images produced from the experience that has been lived and invites a reflection on the silent voices of things in space, the invisible vision and the internal resonance of the subject as well. 